\title{
Acid gelation of whey protein microbeads of different sizes
}

\author{
Robi Andoyo ${ }^{1,2,3}$ - Fanny Guyomarc'h ${ }^{1,2}$. \\ Marie-Hélène Famelart ${ }^{1,2}$
}

Received: 1 June 2015 / Revised: 3 September 2015 / Accepted: 7 September 2015 /

Published online: 30 September 2015

(C) INRA and Springer-Verlag France 2015

\begin{abstract}
In acidified dairy products, the size of the whey protein particles could play a key role in the final structure of the gel. In the present study, small (SM; $2.5 \pm 1.2 \mu \mathrm{m}$ ), medium (MM; 4.2 $\pm 2.2 \mu \mathrm{m})$, and large (LM; 18.4 $\pm 7.2 \mu \mathrm{m})$ whey protein microbeads were produced by mixing a $150 \mathrm{~g} \cdot \mathrm{kg}^{-1}$ whey protein isolate (WPI) solution and $n$ dodecane in the presence of polyglycerolpolyricinoleate (PGPR) surfactant at different shear rates and were then stabilized through heat gelation. The microbeads were then washed by centrifugation, dispersed at 70 or $90 \mathrm{~g} . \mathrm{kg}^{-1}$ in milk ultrafiltrate, and acidification was performed at $35{ }^{\circ} \mathrm{C}$ by adding glucono- $\delta$-lactone to achieve the final $\mathrm{pH}$ of $\sim 4.5$ in $6 \mathrm{~h}$. Acid gelation was monitored using small deformation rheology, while the gel microstructure was investigated microscopically. The results showed that smaller size of microbeads promoted gels with a higher stiffness and a smaller pore size distribution. The effects were particularly significant at SM microbeads as the number of particles in this system was higher than in LM or MM, hence more connectivity between particles.
\end{abstract}

Keywords Whey proteins $\cdot$ Microbeads $\cdot$ Size $\cdot$ Acid gel $\cdot$ Rheology $\cdot$ Microstructure

\section{Introduction}

The design of nanoparticles or microparticles of whey proteins with tailored geometries and physicochemical properties has received great interest in the latest decade (Nicolai et al. 2011; Sağlam et al. 2014c).Numerous applications are envisaged, especially for

Marie-Hélène Famelart

marie-helene.famelart@rennes.inra.fr

1 INRA, UMR1253, Science et Technologie du Lait et de l'CEuf, 65 rue de St Brieuc, F-35042 Rennes cedex, France

2 AGROCAMPUS OUEST, UMR 1253, Science et Technologie du Lait et de l'Euf, 65 rue de St Brieuc, F-35042 Rennes cedex, France

3 Faculty of Agriculture Industrial Technology, Padjadjaran University, Jawa Barat, Indonesia 
the control of rheological properties in food (Purwanti et al. 2012; Giroux et al. 2015; Westerik et al. 2015) including fat replacement in dairy foodstuff (Janhoj and Ipsen 2006; Celigueta Torres et al. 2009) or the improvement of emulsion and/or particle stability (Sağlam et al. 2014a; Çakır-Fuller 2015; Zhang and Zhong 2010). Recent prospects also investigate the encapsulation of bioactive or sensible compounds, or of living micro-organisms, into edible particles (Giroux and Britten 2011; Doherty et al. 2012; Sadeghi et al. 2014).

Essentially, three technological approaches are used to produce such microparticles (Sağlam et al. 2014a). Earlier strategies used the heat denaturation of the whey protein solutions in various conditions of protein concentration, $\mathrm{pH}$, and ionic environment, also combined with shear or homogenization during or after heat-treatment to breakdown particles. However, modification of concentration, $\mathrm{pH}$, or ionic environment also affects the aggregation mechanism, the density and/or the internal structure of the aggregates, the involvement of ions or the thiol/disulfide balance, which can all also affect the gelation properties (Morand et al. 2011a; Nicolai et al. 2011). A more subtle approach is to use thermodynamic equilibrium to coacervate whey proteins into a separated phase of high-protein microbeads (Bouhallab and Croguennec 2013), with possible sophistication involving addition of inert biopolymers and/or heat (Sağlam et al. 2014a). As resulting from equilibrium, the particles are often not stable upon e.g. acidification but raise great interest a means to produce switchable vehicles to deliver bioactives upon variation of the environmental conditions. The third approach, microemulsification, is a drastic - and historical - form of the latter, where an aqueous protein solution is dispersed and stabilized into oil in the presence of surfactant molecules. A major interest of microemulsions is the possibility to control size and roughness of spherical particles with possible decoupling of internal composition and structure (Zhang and Zhong 2010; Saglam et al. 2012; Westerik et al. 2015).

In the present research, we aimed at investigating the role of the size of heatdenatured whey protein particles on acid gelation, in the general context of understanding yoghurt-making mechanisms. To do this, heat-denatured whey protein particles were needed, with varying sizes but with essentially constant other physicochemical properties, both on the surface and inside.

To date, little research has been published on the use of controlled size whey protein microparticles in order to control acid gel texture. Ju and Kilara (1998) or Britten and Giroux (2001) used variation in calcium concentration and/or $\mathrm{pH}$ to produce whey protein aggregates of various sizes from heated dilute solutions and found that largest aggregates yielded gels with lowest firmness, hardness, and/or elasticity. Celigueta Torres et al. (2009) showed that it was possible to produce microparticulated whey protein particles with different sizes through heat-shear process and showed that acid-gel viscosity was inversely correlated with size. However, in these studies, many other factors were at play, e.g., protein concentration (Ju and Kilara 1998), shape and internal structure (Britten and Giroux 2001), and/or the amount of native proteins (Torres et al. 2011).

Hence, the first objective of this study was to describe the formation of whey protein particles of different sizes but constant other physicochemical properties, having a defined spherical geometry, called whey protein "microbeads." The second objective was then to evaluate the effect of their size on the acid gelation. To do this, emulsification was used to create a water in oil (w/o) emulsion, in which the WPI solution was 
used as the dispersed phase and using a high speed mixer in the presence of an oilsoluble emulsifier (Saglam et al. 2012). Therefore, in the present study, whey protein microbeads of different sizes were produced, stabilized through heat gelation, then washed, and redispersed in milk ultrafiltration permeate to assess their acid gelation at a constant total protein concentration (i.e., constant volume fraction).

\section{Materials and methods}

\subsection{Materials}

A commercial whey protein isolate (WPI) (Prolacta 95, Lactalis Ingredients, Bourgbarré, France) was used as the source of protein. The protein content of WPI powder was $\sim 939$ g. $\mathrm{kg}^{-1}$ dry matter determined by the Kjeldahl method using 6.38 as conversion factor. Milk ultrafiltration permeate (MUF) containing the aqueous phase of milk (water and dialyzable solutes such as lactose and ions) was produced from microfiltration then ultrafiltration of raw skim milk (Schuck et al. 1994) and stored at $5{ }^{\circ} \mathrm{C}$ after addition of 0.2 g. $\mathrm{L}^{-1}$ sodium azide $\left(\mathrm{NaN}_{3}\right)$ to ensure biological stability during experiments. Polyglycerolpolyricinoleate (Grindsted PGPR 90, Denmark) was purchased from Danisco and contained a polyglycerol ester of polycondensedricinoleic acid with added antioxidants $\alpha$-tocopherol (E 307; max 200 ppm) and citric acid (E330; $\max 200 \mathrm{ppm}$ ). $n$-Dodecane (non-food-grade) was purchased from Merck, having a density of $0.748 \mathrm{~kg} . \mathrm{L}^{-1}$ at $20{ }^{\circ} \mathrm{C}$. All other chemicals were of analytical grade quality. PGPR is a food-grade surfactant that has proven efficient of the proposed approach (Saglam et al. 2012). The present research pursue academical objectives but may open perspectives for possible application providing that $n$-dodecane is replaced and/or that nonprotein additives are entirely removed, as in Zhang and Zhong (2010).

\subsection{Formation of whey protein microbeads by emulsification}

WPI solution at 150 g. $\mathrm{kg}^{-1}$ of protein was produced by diluting the WPI powder in deionized water with $0.2 \mathrm{~g} \cdot \mathrm{kg}^{-1} \mathrm{NaN}_{3}$, stirring for $2 \mathrm{~h}$, filtering on $0.45-\mu$ m hydrophilic syringe filter (Minisart, Sartorius syringe filter) and then left at $4{ }^{\circ} \mathrm{C}$ overnight for complete hydration. PGPR ( $\left.25 \mathrm{~g} . \mathrm{kg}^{-1}\right)$ was dissolved in $n$-dodecane by stirring for $1 \mathrm{~h}$ at $40{ }^{\circ} \mathrm{C}$. A water in $n$-dodecane (w/o) emulsion ( $20 \mathrm{~g}$ ) was prepared by mixing the WPI solution ( $2 \mathrm{~g}$ ) with $n$-dodecane plus PGPR (18 g), using a high speed mixer (Ultraturrax T18 basic, IKA Werke, Germany). According to Wilson et al. (1998), Kobayashi et al. (2005), and Saglam et al. (2012), the presence of PGPR is important to help forming and stabilizing the whey protein microdroplets in the hydrophobic continuous phase by lowering the interfacial tension, and hence the stress needed to break up droplets into smaller particles is reduced. Surfactants also prevent coalescence of newly formed microbeads (Tadros 2013). Different sizes of whey protein microdroplets were produced by mixing the w/o emulsions at different speeds, i.e., 7,200, 15,600, and 24,200 rpm for $5 \mathrm{~min}$, and were called large (LM), medium (MM), and small (SM) size whey protein microdroplets, respectively. Directly after preparation, the w/o emulsion was dispensed in sealed 5 -g glass tubes and heated at $75^{\circ} \mathrm{C}$ for $20 \mathrm{~min}$ in a temperature-controlled water bath, in order to heat-gel the microdroplets and form 
stable microbeads, and then rapidly cooled in ice water to room temperature. A preliminary experiment had been done to determine the appropriate heat-load to be applied to the emulsion systems to ensure complete heat-gelation of the droplets. Several heating temperature and time combinations were applied to the WPI solution of 150 g. $\mathrm{kg}^{-1}$, and the firmness of the gels was measured using penetrometry. The results showed that heat treatment at $75{ }^{\circ} \mathrm{C}$ for $20 \mathrm{~min}$ was sufficient to gel the whey protein solution at $150 \mathrm{~g} \cdot \mathrm{kg}^{-1}$ as showed by a high increase of the gel firmness as compared to the gel produced with the other temperature/time combinations (results not shown). Centrifugation at $5000 \mathrm{x} g$ for $10 \mathrm{~min}$ (Heraeus Biofuge Primo R, IMLAB, Lille, France) through an oil-water interface was performed on the heated emulsions $(20 \mathrm{~g}$ emulsion $+20 \mathrm{~g}$ distilled water in a $50-\mathrm{mL}$ tube) in order to collect the microbeads into water. During this centrifugation, the microbeads were transferred into the water phase where they pelleted. The $n$-dodecane phase and excess water were pipetted out and replaced by water in which the microbeads were redispersed and remained stable. Subsequent centrifugation and redispersion in water were then used to complete washing of the microbeads and replacement of the $n$-dodecane with distilled water. This step was repeated twice. A final dispersing step was performed using MUF. The protein content of the resulting whey protein microbeads suspended in MUF was determined spectrophotometrically at $280 \mathrm{~nm}$ after having dissolved the beads in $8 \mathrm{M}$ urea, $0.05 \mathrm{M}$ citrate tri-sodium, 5 g. $\mathrm{L}^{-1}$ sodium dodecyl sulfate, $0.2 \mathrm{M}$ 2-amino-2-

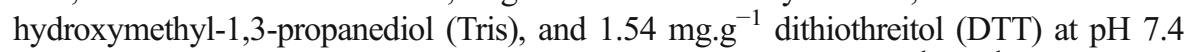
and using an experimental extinction coefficient value of $1.2244 \mathrm{~L} . \mathrm{g}^{-1} . \mathrm{cm}^{-1}$ as in Morand et al. (2011b) and buffer as a blank. Whey protein microbead dispersions were eventually standardized at 70 and 90 g. $\mathrm{kg}^{-1}$ protein using MUF as the dispersant. Preparation of the microbeads was performed at least twice of each size of sample. At the end of preparation, the microbeads were assumed to contain no more than traces of $n$ dodecane and PGPR.

\subsection{Characterization of the microbeads}

\subsubsection{Isoelectric $p H$ value}

The isoelectric $\mathrm{pH}(\mathrm{pI})$ of the whey protein microbeads suspended in MUF was determined as the $\mathrm{pH}$ value at which the electrophoretic mobility of the beads was zero. The $\mathrm{pH}$ of the dispersion of whey protein microbeads was varied from 3 to 6 using dilution into a $0.1 \mathrm{M}$ citric acid and sodium phosphate buffer (viscosity 1.1454 Pa.s, refractive index 1.337, and dielectric constant 80.4 ). The electrophoretic mobility was measured at $50 \mathrm{~V}$ and at $20{ }^{\circ} \mathrm{C}$ on a Zeta sizer nano ZS equipment (Malvern Instruments, Orsay, France) using a laser at $633 \mathrm{~nm}$. The value of the $\mathrm{pI}$ was inferred from interpolation of the mobility to 0 . Experiment was performed twice for each type of sample.

\subsubsection{Optical microscopy}

Samples were imaged at three different steps during the formation of whey protein microbeads, namely before and after heat treatment while being dispersed in $n$ dodecane and after heat treatment and dispersion in MUF. The microbeads were 
analyzed using an optical microscope (BX51, Olympus, Rungis, France). Samples were diluted $5 \times$ by using the appropriate solvent phase ( $n$-dodecane or MUF depending on the step). A drop of diluted sample was transferred on a microscope slide and covered with a coverslip prior to analysis. Lens of $\times 10$ magnification was used. The size (diameter) of each microbead in the image (three images per sample $\times 2$ replications) was scaled manually, and a histogram analysis tool in Microsoft Excel was used to plot the cumulative frequencies on each class of size.

\subsection{Confocal laser scanning microscopy of the gel}

Samples for confocal images measurement were prepared as described by Andoyo et al. (2014). Briefly, the bead dispersions were equilibrated at $35^{\circ} \mathrm{C}$, labeled using $0.06 \mu \mathrm{L}$ of rhodamine B isothiocyanate (RITC) per gram of protein and stirred for $15 \mathrm{~min}$ prior to the addition of glucono-delta-lactone (GDL, from Merck, Sigma Aldrich). It was previously shown that labeling does not affect the course of acid gelation (Vasbinder et al. 2004; Guyomarc'h et al. 2009). GDL was added as a powder into the sample to induce gelation at $35{ }^{\circ} \mathrm{C}$. Immediately after the addition of GDL, $\sim 60 \mu \mathrm{L}$ of the labeled sample was deposited on a conclave glass slide, covered with a cover slip, sealed with nail varnish, and incubated at $35^{\circ} \mathrm{C}$ until $\mathrm{pH} 4.5$. The rest of the sample was incubated in a water bath, and its $\mathrm{pH}$ was measured with a $\mathrm{pH}$ meter (Consort C931, Bioblock, France) equipped with Inlab $415 \mathrm{pH}$ electrode (Mettler-Toledo, Viroflay, France). When the sample in the bath reached $\mathrm{pH} 4.5$, the slides were imaged at $543 \mathrm{~nm}$ through the cover slip using a TE2000E Nikon C1i inverted confocal laser scanning microscope (CLSM, Nikon, Champignysur-Marne, France). Each image was digitized in gray levels as a $512 \times 512$ pixel matrix $\left(127.3 \times 127.3 \mu \mathrm{m}^{2}\right)$. Ten images were analyzed per sample.

\subsection{Rheological characterizations of the gels}

The dispersed microbeads were equilibrated at $35^{\circ} \mathrm{C}$, then 12.63 or $15.10 \mathrm{~g} \cdot \mathrm{kg}^{-1}$ of GDL was added to the 70 or $90 \mathrm{~g} . \mathrm{kg}^{-1}$ microbead dispersions, respectively, to achieve a final $\mathrm{pH}$ of 4.5 within $6 \mathrm{~h}$. The sample was stirred for $1 \mathrm{~min}$, and the suspension was then transferred to the AR2000 rheometer (TA Instruments, Guyancourt, France) equipped with cone-plate geometry (diameter $6 \mathrm{~cm}$ and cone angle $4^{\circ}$ ). Acid gelation was followed by measuring the elastic modulus, $G^{\prime}$ (in $\mathrm{Pa}$ ), with time and $\mathrm{pH}$, using the oscillatory mode at $35{ }^{\circ} \mathrm{C}$, with a frequency of $1 \mathrm{~Hz}$ and $0.1 \%$ strain. Low-density paraffin was added around the sample to prevent evaporation. The gelation $\mathrm{pH}$ was defined as the moment when $G^{\prime}>1 \mathrm{~Pa}$, while the value of $G^{\prime}$ at $\mathrm{pH} 4.5$ was considered to be the final $G^{\prime}$ at $35^{\circ} \mathrm{C}$ $\left(G_{\text {max }}^{\prime}\right)$. Two measurements were performed for each independent sample.

\section{Results and discussion}

\subsection{Formation and microstructure of whey protein microbeads}

Optical microscopy images of the whey protein microdroplets obtained through emulsification at increasing mixing speed of the $150 \mathrm{~g} . \mathrm{kg}^{-1}$ WPI suspension in $n$-dodecane and before heat treatment are shown in Fig. 1. At $7200 \mathrm{rpm}$, large microdroplets (LM) 
were formed that could reach over $10 \mu \mathrm{m}$ in diameter (Fig. 1a). To form smaller droplets, higher speed of emulsification was applied, providing the energy needed to expand the total surface of whey protein droplets into smaller ones (Tadros 2013). Figure shows that when using stirring speeds of 15,600 or $24,200 \mathrm{rpm}, \mathrm{MM}$ and SM microdroplets of a few micrometers or less can be obtained. At this stage, size distribution analysis showed that the microdroplets had a spherical shape and mean diameters of $\sim 15.7 \pm 8.1$, $2.3 \pm 1.2$, and $1.3 \pm 0.8 \mu \mathrm{m}$ for LM, MM, and SM systems, respectively (Fig. 3). Diameters of 1 to $16 \mu \mathrm{m}$, as produced in the current study, were notably larger than the size of the whey protein aggregates generally observed after the heat treatment of milk.

Figure 2 shows the MM microbeads at the various steps of the process. Figure 2a shows the MM microdroplets after stabilization into microbeads by heat gelation at

Fig. 1 Whey protein microbeads of different sizes, dispersed in $n$ dodecane before heat treatment. Large (a), medium (b), and small (c) size of microbeads produced at different speeds of emulsification
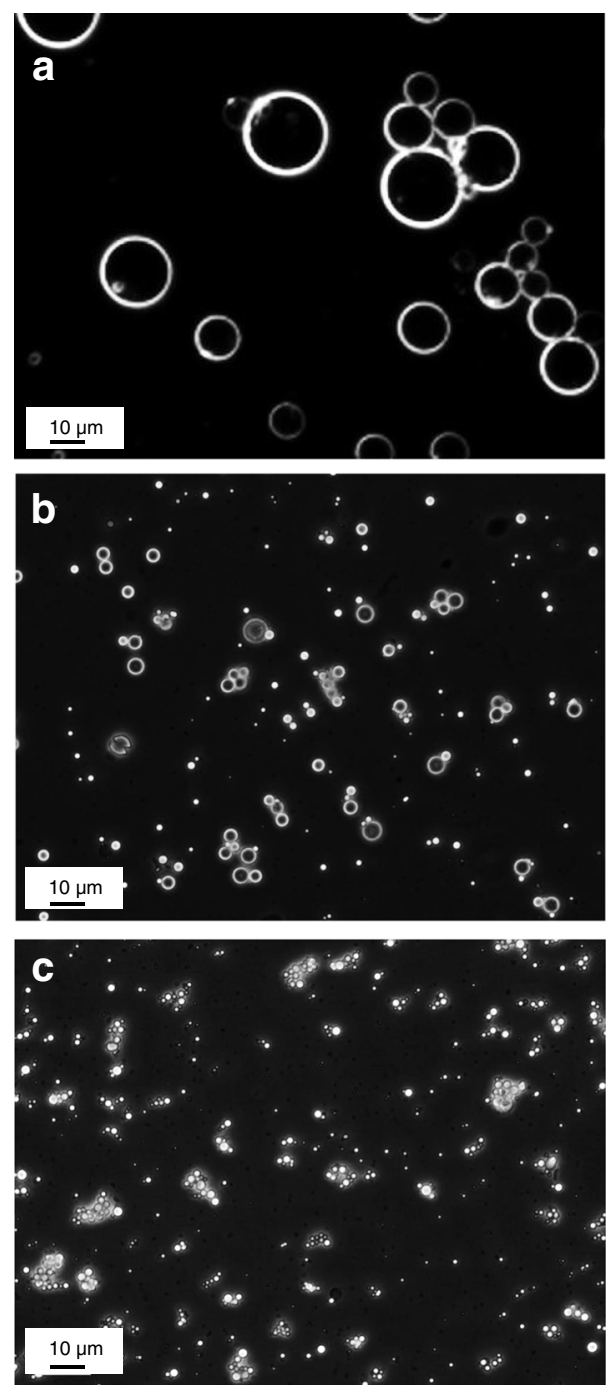
$75^{\circ} \mathrm{C}$ for $20 \mathrm{~min}$ in the oil phase. In spite of the heat treatment, the images show that both the shape and size of the MM whey protein microbeads were unaffected by heating $(p>0.05)$. At this stage, the mean diameters of the LM, MM, and SM were found to be $\sim 14.5 \pm 6.8,2.4 \pm 1.3$, and $1.3 \pm 0.7 \mu \mathrm{m}$, respectively (Fig. 3). Furthermore, the heated microbeads tended to have slightly different optical properties as shown through their whiter aspect. Similar observations were also made for the SM and LM systems (results not shown).

Figure $2 \mathrm{~b}$ shows the optical microscopy images of MM whey protein microbeads after centrifugation, washing, and dispersion into MUF. At this stage, the mean diameters of the LM, MM, and SM were found to be $\sim 18.4 \pm 7.2,4.2 \pm 2.2$, and $2.5 \pm$ $1.2 \mu \mathrm{m}$, respectively (Fig. 3). The shape of the whey protein microbeads was spherical as in the previous steps, but they have enlarged, as indicated by the significant $p<0.001$ for the three comparisons between diameters measured in dodecane after heating and in MUF. This increase in diameter is probably a result of the replacement of the $n$ dodecane by MUF after centrifugation and washing steps and although having been heat-gelled. This swelling phenomenon was attributed to the osmotic absorption of water by the whey protein microbeads, due to their high protein concentration and to the water absorption capacity of the protein (Gunasekaran et al. 2006; Purwanti et al. 2012). In a separate experiment, an aqueous solution of 150 g. $\mathrm{kg}^{-1}$ whey proteins was introduced in a glass tube, weighed and covered by $n$-dodecane. The glass tube was then heated as in the current study. Then, $n$ dodecane was replaced with water. Every 30 min during $4 \mathrm{~h}$, water was removed from one tube, and the gel weighed. The weight of the heat-induced whey protein gels was increased by about $50 \%$ after $4 \mathrm{~h}$ of storage in water (result not shown). Therefore, absorption of water or MUF by the whey protein microbeads was the cause of the particle swelling. We found that the diameter increase of the beads was of 1-2 $\mu \mathrm{m}$, i.e., $16 \%$ for $\mathrm{LM}, 88 \%$ for MM, and $90 \%$ for SM. Swelling was possibly related to a transfer phenomenon as transfer processes are proportional to the surface of exchange and as the specific surface of the smaller beads was larger than that of larger ones at the same volume fraction. The following equation gives the relation between the osmotic pressure, $\pi$, of an aqueous fraction and the water activity, $a_{w}$ :

$$
\pi=-\frac{R T}{V_{m o l}^{H_{2} O}} \log _{n}\left(a_{w}\right)
$$

with $V_{m o l}^{\mathrm{H}_{2} \mathrm{O}}$ as the molar volume of water and $a_{w}$ as the water activity. When the beads are in $n$-dodecane, the $a_{w}$ of $n$-dodecane is close to 0 , and $\pi$ applied by $n$-dodecane is lower than $\pi$ inside the beads. Hence, beads in $n$-dodecane would have the tendency to lose their water molecules and to shrink. MUF has a larger $a_{w}$, close to 1, and applies a higher osmotic pressure than inside the beads, so that water molecules were transferred from the MUF phase into the beads, which induced swelling. This swelling was probably restricted by the elastic properties of the heat-stabilized microbeads and stopped when the transfer strength equaled the mechanical strength of the gel inside the beads. Particle swelling may also have changed the internal properties of the microbeads such as their voluminosity. Even though the volume of LM beads only slightly varied, that of the MM and SM was increased sixfold to sevenfold. Hence, the volume fractions of the 
Fig. 2 Whey protein microbeads of medium size after heat treatment: dispersed in $n$-dodecane (a) or dispersed in milk ultrafiltrate (b)
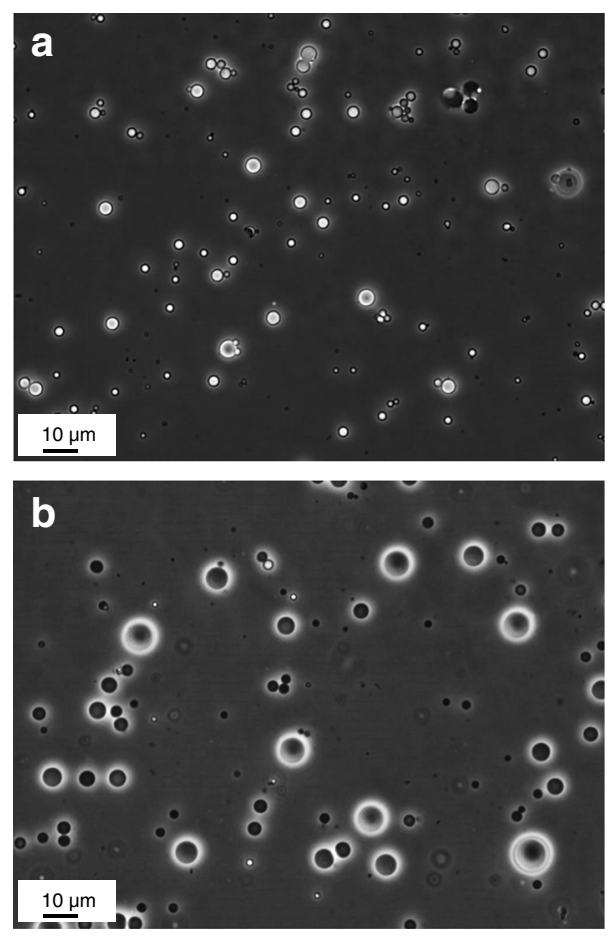

two latter samples remained comparable but could not be compared with that of LM suspensions.

The isoelectric $\mathrm{pH}(\mathrm{pI})$ values of the $\mathrm{LM}, \mathrm{MM}$, and SM whey protein beads in MUF were determined to be $4.7,4.8$, and $4.9 \pm 0.1$, respectively (Fig. 4). These values were

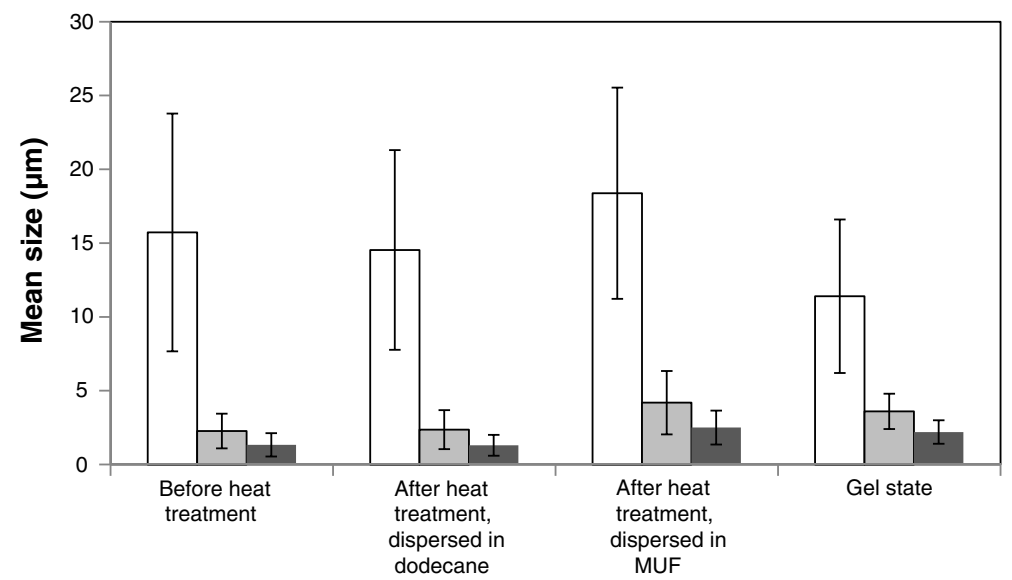

Fig. 3 Mean size and standard deviation of whey protein microbeads prepared at different emulsification speeds and measured at different stages of preparation: large microbeads (LM) (white square), medium microbeads (MM) (gray square), and small microbeads (SM) (black square). Vertical bars indicate standard deviations. MUF is milk ultrafiltrate. The results are from two independent preparations and different images (see text for details) 
not significantly different whatever the droplet sizes $(P>0.05)$, i.e., reducing the diameter of whey protein microbeads from $\sim 15$ to $1.3 \mu \mathrm{m}$ did not change their $\mathrm{pI}$ value. This was in compliance with the objective of the study to have beads of various sizes but similar physicochemical properties, especially the pI. Furthermore, these values were in accordance with the $\mathrm{pI}$ values found by other authors for heat-induced whey protein aggregates produced by heating whey proteins in aqueous solution at neutral $\mathrm{pH}$ values, ranging from 4.7 to 4.9 (Jean et al. 2006; Morand et al. 2012). Therefore, the microbeads exhibited expected pI values for denatured whey protein particles. However, traces of PGPR cannot be excluded.

\subsection{Acid gelation of whey protein microbeads}

Figure 5 shows the storage modulus $\left(G^{\prime}\right)$ of acid gels made from microbead suspensions of different sizes and at different total protein concentrations as a function of $\mathrm{pH}$ upon acidification. The $G^{\prime}$ showed a sharp increase from the point where the gel was formed $\left(G^{\prime}>1 \mathrm{~Pa}\right)$ and then leveled off toward $G_{\text {max }}^{\prime}$. Increasing the size of whey protein microbeads at any total protein concentrations did not change the $\mathrm{pH}$ of gelation, i.e., they gelled at about the same $\mathrm{pH}(\sim 5.7)$. The results furthermore show that the SM system yielded the highest $G_{\max }^{\prime}$ among the three systems at $70 \mathrm{~g} . \mathrm{kg}^{-1}$ initial protein concentration, reaching $\sim 10 \mathrm{~Pa}$ for the SM system, and below $5 \mathrm{~Pa}$ for the LM and MM systems. For the systems at $90 \mathrm{~g} \cdot \mathrm{kg}^{-1}$ initial protein concentration, the $G_{\text {max }}^{\prime}$ value was above $40 \mathrm{~Pa}$ for SM system and 25-30 $\mathrm{Pa}$ for the LM and MM systems. Therefore, small microbeads produced stronger acid gels; however, the gelation of MM and LM systems seemed very similar in spite of the significant reduction in bead size in MM as compared to LM (Fig. 3). Even though changes in voluminosity occurred upon dispersion of the microbeads into MUF, the expected impact of volume fraction onto elasticity did not fully explain the results since the SM and MM samples could yet be regarded as having similar volume fraction but different bead sizes. On the other hand, MM and LM microbeads had notably different voluminosities and yet did not show

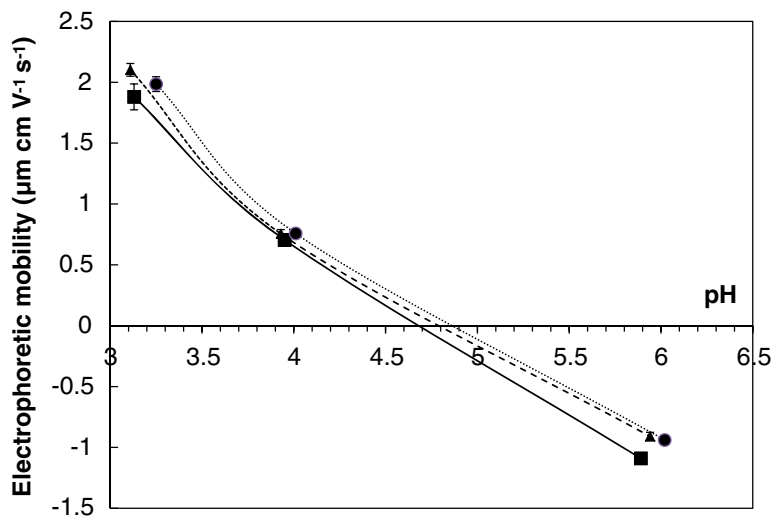

Fig. 4 Electrophoretic mobility and standard deviation of whey protein microbeads prepared by emulsification of whey proteins in the presence of PGPR, then heating and collecting into MUF. Microbeads of different sizes measured in $0.1 \mathrm{M}$ citric acid and $0.1 \mathrm{M}$ sodium phosphate buffer: large microbeads (LM) (black square), medium microbeads (MM) (black triangle), and small microbeads (SM) (black circle). The results are from two independent measurements 
much difference in $G_{\text {max }}^{\prime}$. Increasing the initial protein concentration of the system from 70 to $90 \mathrm{~g} . \mathrm{kg}^{-1}$ led to the increase of $G_{\text {max }}^{\prime}$ for more than five times at any size of whey protein microbeads. Andoyo et al. (2015) showed that increasing the concentration of particles indeed increased the final $G_{\text {max }}^{\prime}$ values of acid gels.

Hence, it seemed that small particle size favored the development of more elastic acid gels. This result confirmed previous findings and provided further detail on the effective role of particle size in gel formation, through decoupling size from other factors like composition, nature of the interactions, or shape that were also present in Ju and Kilara (1998), Britten and Giroux (2001), or Torres et al. (2011). van Riemsdijk et al. (2011) studied the formation of whey protein particles by using shear flows to control the protein particle size and found that reducing the size of whey protein microparticles from $\sim 20$ to $2.5 \mu \mathrm{m}$ could increase the final $G^{\prime}$ value of acid-induced WPI-locust bean gum co-gels more than 15 times. Smaller size of the whey protein microbeads, as in SM systems, means that the number of particles was larger in the system at the same total protein concentration. Considering homogenous spheres of monodisperse radius, one can calculate that $\sim 90$ beads of MM and $\sim 400$ beads of SM occupy the volume of 1 LM. van Riemsdijk et al. (2011) suggested that the physical interactions between protein particles could be responsible for the network formation of the whey protein clusters. Furthermore, the formation of whey protein clusters was favored by smaller particle size due to an increased number of particle interactions. However, the increase in $G_{\max }^{\prime}$ could not be linearly correlated with the size (or number) of microbeads in the samples, since the MM and LM gelation curves could hardly be differentiated at either tested concentration. Possibly, a maximum threshold value of particle size may exist that is required for the gel to properly fill the sample volume. When using microparticulated whey proteins in dairy gel applications, it is known that too large particles (typically $>1-10 \mu \mathrm{m}$ ) reduce the cohesion and firmness of acid gels (Celigueta Torres et al. 2009). Sağlam et al. (2014b) furthermore showed that inclusion of protein-dense microbeads into heat-set whey protein gels strongly lowered their mechanical elasticity.

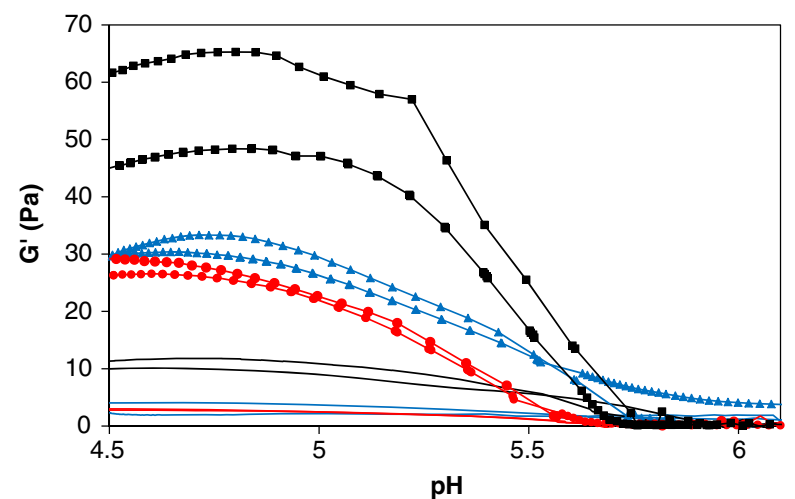

Fig. 5 Storage modulus $\left(G^{\prime}\right)$ as a function of $\mathrm{pH}$ recorded during acidification at $35{ }^{\circ} \mathrm{C}$ of whey protein microbeads at different total protein concentrations: lines with black square, black triangle, and black circle were whey protein microbeads at total protein concentration of $90 \mathrm{~g} \cdot \mathrm{kg}^{-1}$, and lines without symbol were for whey protein microbeads at total protein concentration of $70 \mathrm{~g} \cdot \mathrm{kg}^{-1}$. Blue, red, and black colors indicate the LM, MM, and SM systems respectively. Full lines in the same color indicate repetitions (For interpretation of the references to colour in this figure legend, the reader is referred to the web version of this article) 


\subsection{Microstructure of the microbead gel}

The microstructure of the whey protein microbead gels at $70 \mathrm{~g} \cdot \mathrm{kg}^{-1}$ protein was imaged at $\mathrm{pH} \sim 4.5$ with CSLM (Fig. 6). The whey protein microbeads, shown as white spherical objects, seemed to have retained the same shape and similar size as before gelation. It was impossible to measure the size of the gelled particles with batch methods, due to continuity across objects, but manual measurements estimated the bead diameters to be $11.4 \pm 5.2,3.6 \pm$ 1.2, and $2.2 \pm 0.8 \mu \mathrm{m}$ for the LM, MM, and SM microbeads, respectively (Fig. 3; histogram in Fig. 6). In these matrices, the whey protein microbeads were connected through contact between their surfaces and were still visible as intact spheres. Decreasing the size of whey protein microbeads tended to produce a more homogenous gel as indicated by the smaller pores (black color) on the confocal micrographs of SM (Fig. 6c) compared to MM or LM (Fig. 6a, b) which seemed to exhibit larger pore sizes. These results were in line with the rheological measurements, where the $G^{\prime}$ curves of the LM and MM gels were hardly differentiated at either total protein concentrations tested. The number of microbeads particles in the SM gel was hundred times higher than in LM and almost 2 decades higher than in MM gel, and hence, distances were shorter between particles while total surface increased; therefore, more junctions and bonds were produced between particles, which might account for the smaller porosity and the higher $G_{\max }^{\prime}$ value (Andoyo et al. 2014). Interestingly, the $G_{\max }^{\prime}$ value of the microbead gels was far lower than gels made with $\sim 0.1-\mu \mathrm{m}$ large whey protein aggregates (WPA) at the same concentration. For instance, Morand et al. (2012) found that WPA with a diameter of $110 \mathrm{~nm}$ yielded $G_{\text {max }}^{\prime}$ values of $\sim 100 \mathrm{~Pa}$ at $20 \mathrm{~g} \cdot \mathrm{kg}^{-1}$. A possible reason for the low $G^{\prime}$ values found in this report is that the
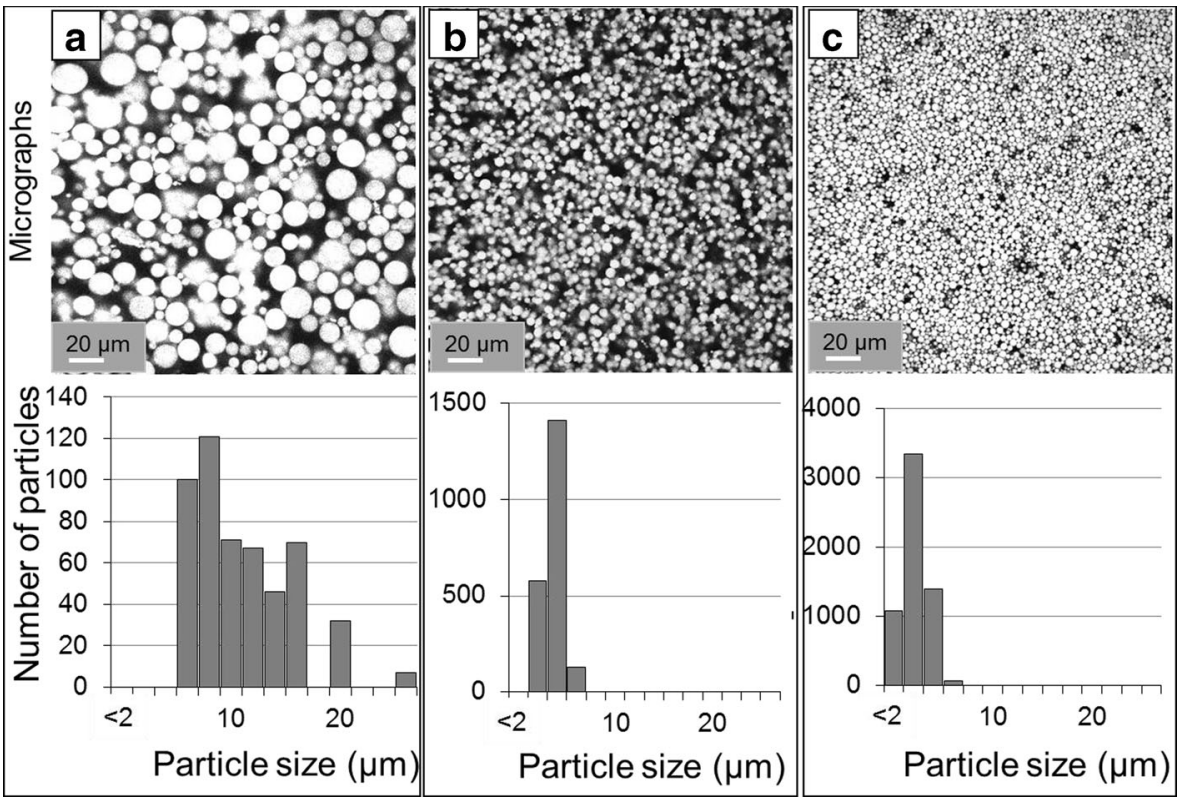

Fig. 6 Confocal laser scanning micrographs of the acid gels from large (a), medium (b), and small microbeads (c) whey protein microbeads at $\mathrm{pH} 4.5$ at $70 \mathrm{~g} \cdot \mathrm{kg}^{-1}$ protein. Histogram bellow the confocal micrograph is the population of the particles on each size class. Three micrographs were analyzed per preparation 
surface developed by the SM-LM microbeads was very small compared to the surface developed by aggregates of 100-nm diameter. Considering homogenous spheres of monodisperse radii, one can calculate that SM and MM respectively develop 7.5 and 4.5 times more surface than LM, for a given volume fraction of microbeads. Meanwhile, $0.1-\mu \mathrm{m}$ WPA particles will develop 185 times more surface, for the same volume fraction. If there was a limited number of sites per surface unit, e.g., hydrophobic patches, the higher the surface of active particles, the higher the number of connections and the higher the $G^{\prime}$, in a nonlinear (possibly exponential) manner. For large particles, results suggest that a maximum diameter is reached at about a few micrometers above which $G^{\prime}$ is minimal.

\section{Conclusion}

In conclusion, we found that whey protein microbeads of different sizes could be used as a model way to manipulate properties of acid gels by influencing the connectivity and porosity of the gel. Particle interactions were favored by a smaller size of whey protein microbeads as confirmed by the highest $G_{\max }^{\prime}$ value and smallest pore size of the gels made out of the smallest microbeads.

Acknowledgments We wish to thank the Directorate General of Higher Education of the Ministry of Education and Culture of the Republic of Indonesia, for funding through scholarship overseas program.

\section{References}

Andoyo R, Guyomarc'h F, Burel A, Famelart M-H (2015) Spatial arrangement of casein micelles and whey protein aggregate in acid gels: insight on mechanisms. Food Hydrocoll 51:118-128

Andoyo R, Guyomarc'h F, Cauty C, Famelart M-H (2014) Model mixtures evidence the respective roles of whey protein particles and casein micelles during acid gelation. Food Hydrocoll 37:203-212

Bouhallab S, Croguennec T (2013) Spontaneous assembly and induced aggregation of food proteins. In: Müller M (ed) Polyelectrolyte complexes in the dispersed and solid state II. Springer, Heidelberg, pp 67101

Britten M, Giroux HJ (2001) Acid-induced gelation of whey protein polymers: effects of $\mathrm{pH}$ and calcium concentration during polymerization. Food Hydrocoll 15:609-617

Çakır-Fuller E (2015) Enhanced heat stability of high protein emulsion systems provided by microparticulated whey proteins. Food Hydrocoll 47:41-50

Celigueta Torres I, Ipsen R, Knudsen JC, Ostergaard BB (2009) Microparticulated whey protein as fat replacer in yoghurt. In: Celigueta Torres I (ed). ETH Zurich, Switzerland, pp 404-407

Doherty SB, Auty MA, Stanton C et al (2012) Survival of entrapped Lactobacillus rhamnosus GG in whey protein micro-beads during simulated ex vivo gastro-intestinal transit. Int Dairy J 22:31-43

Giroux HJ, Britten M (2011) Encapsulation of hydrophobic aroma in whey protein nanoparticles. J Microencapsul 28:337-343

Giroux HJ, Lanouette G, Britten M (2015) Effect of whey protein aggregates of various sizes on the formation and properties of rennet-induced milk gels. Food Hydrocoll 45:272-278

Gunasekaran S, Xiao L, Eleya MMO (2006) Whey protein concentrate hydrogels as bioactive carriers. J Appl Polym Sci 99:2470-2476

Guyomarc'h F, Jemin M, Le Tilly V, et al (2009) Role of the heat-induced whey protein/K-casein complexes in the formation of acid milk gels: a kinetic study using rheology and confocal microscopy. In: Famelart $\mathrm{MH}$ (ed)

Janhoj T, Ipsen R (2006) Effect of pre-heat treatment on the functionality of microparticulated whey protein in acid milk gels. Milchwissenschaft 61:131-134 
Jean K, Renan M, Famelart MH, Guyomarc'h F (2006) Structure and surface properties of the serum heatinduced protein aggregates isolated from heated skim milk. Int Dairy J 16:303-315

Ju ZY, Kilara A (1998) Aggregation induced by calcium chloride and subsequent thermal gelation of whey protein isolate. J Dairy Sci 81:925-931

Kobayashi I, Lou X, Mukataka S, Nakajima M (2005) Preparation of monodisperse water-in-oil-in-water emulsions using microfluidization and straight-through microchannel emulsification. J Am Oil Chem Soc 82:65-71

Morand M, Guyomarc'h F, Famelart MH (2011a) How to tailor heat-induced whey protein/-casein complexes, as a means to investigate the acid gelation of milk - a review. Dairy Sci Technol 91:97-126

Morand M, Guyomarc'h F, Legland D, Famelart MH (2012) Changing the isoelectric point of the heatinduced whey protein complexes affects the acid gelation of skim milk. Int Dairy J 23:9-17

Morand M, Guyomarc'h F, Pezennec S, Famelart MH (2011b) On how k-casein affects the interactions between the heat-induced whey protein/k-casein complexes and the casein micelles during the acid gelation of skim milk. Int Dairy J 21:670-678

Nicolai T, Britten M, Schmitt C (2011) $\alpha$-lactoglobulin and WPI aggregates: formation, structure and applications. Food Hydrocoll 25:1945-1962

Purwanti N, Moerkens A, van der Goot AJ, Boom R (2012) Reducing the stiffness of concentrated whey protein isolate (WPI) gels by using WPI microparticles. Food Hydrocoll 26:240-248

Sadeghi S, Madadlou A, Yarmand M (2014) Microemulsification-cold gelation of whey proteins for nanoencapsulation of date palm pit extract. Food Hydrocoll 35:590-596

Sağlam D, Venema P, de Vries R et al (2014a) Whey protein particles modulate mechanical properties of gels at high protein concentrations. Food Hydrocoll 38:163-171

Saglam D, Venema P, de Vries R et al (2012) Relation between gelation conditions and the physical properties of whey protein particles. Langmuir 28:6551-6560

Sağlam D, Venema P, de Vries R, van der Linden E (2014b) Exceptional heat stability of high protein content dispersions containing whey protein particles. Food Hydrocoll 34:68-77

Sağlam D, Venema P, van der Linden E, de Vries R (2014c) Design, properties, and applications of protein micro- and nanoparticles. Curr Opin Colloid Interface Sci 19:428-437

Schuck P, Piot M, M,jean S et al (1994) Déshydratation des laits enrichis en caséine micellaire par microfiltration; comparaison des propriétés des poudres obtenues avec celles d'une poudre de lait ultrapropre. Lait 74:47-63

Tadros TF (2013) Emulsion formation, stability, and rheology. In: Tadros TF (ed) Emulsion formation and stability. Wiley-VCH Verlag GmbH \& Co. KGaA, pp 1-75

Torres IC, Janhoj T, Mikkelsen BO, Ipsen R (2011) Effect of microparticulated whey protein with varying content of denatured protein on the rheological and sensory characteristics of low-fat yoghurt. Int Dairy $\mathrm{J}$ 21:645-655

van Riemsdijk LE, Snoeren JPM, van der Goot AJ et al (2011) New insights on the formation of colloidal whey protein particles. Food Hydrocoll 25:333-339

Vasbinder AJ, van de Velde F, de Kruif CG (2004) Gelation of casein-whey protein mixtures. J Dairy Sci 87: 1167-1176

Westerik N, Scholten E, Corredig M (2015) The effect of calcium on the composition and physical properties of whey protein particles prepared using emulsification. Food Chem 177:72-80

Wilson R, van Schie BJ, Howes D (1998) Overview of the preparation, use and biological studies on polyglycerol polyricinoleate (PGPR). Food Chem Toxicol 36:711-718

Zhang W, Zhong Q (2010) Microemulsions as nanoreactors to produce whey protein nanoparticles with enhanced heat stability by thermal pretreatment. Food Chem 119:1318-1325 